\title{
Gambaran gangguan mental emosional pada penduduk Desa Banfanu, Timor Tengah Utara, Provinsi Nusa Tenggara Timur
}

\author{
Eduardo Renaldo ${ }^{1}$, Eva Suryani ${ }^{2}$
}

\begin{abstract}
ABSTRAK
\section{LATAR BELAKANG}

Kesehatan jiwa merupakan salah satu permasalahan kesehatan yang signifikan di dunia, termasuk di Indonesia. Berdasarkan data Riskesdas, gangguan mental emosional pada populasi Indonesia tahun 2013 adalah 6\%, kemudian pada tahun 2018 meningkat menjadi 9.8\%. Provinsi Nusa Tenggara Timur (NTT) menempati urutan ketiga tertinggi dengan prevalensi $15.7 \%$. Di NTT, penelitian mengenai gangguan mental emosional belum banyak dilakukan, serta belum terfokus pada daerah terpencil atau tertinggal yang ada di dalamnya. Berdasarkan pemaparan tersebut maka peneliti tertarik untuk menggambarkan pola gangguan mental emosional pada penduduk di Desa Banfanu, NTT melalui berbagai faktor sosiodemografik yang menyertai.
\end{abstract}

\section{METODE}

Penelitian ini merupakan penelitian cross-sectional yang melibatkan 80 responden di Desa Banfanu, Timor Tengah Utara, Provinsi Nusa Tenggara Timur. Teknik pengambilan data secara accidental sampling menggunakan instrumen Self Reporting Questionnaire-20 (SRQ20). Teknik analisis data dalam penelitian ini menggunakan distribusi frekuensi. Data yang sudah diklasifikasikan, disajikan dalam bentuk tabel.

\section{HASIL}

Responden yang mengalami gangguan mental emosional 8.8\% dari 80 responden. Karakteristik penduduk yang paling banyak mengalami gangguan mental emosional adalah perempuan (6.3\%), usia muda (15-34 tahun) sebesar 5\%, pendidikan rendah (5\%), dan tidak bekerja $(6.3 \%)$. Gejala somatik (fisik) mendominasi kelompok penduduk umum dan yang mengalami gangguan mental emosional. Beberapa gejala antara lain sakit kepala, sulit tidur, mudah lelah, merasa cemas, tegang atau khawatir, tidak nafsu makan, dan rasa tidak enak di perut.

\section{KESIMPULAN}

Gangguan mental emosional penduduk di Desa Banfanu, Timor Tengah Utara, Provinsi Nusa Tenggara Timur sebesar 8.8\%, dan terbanyak mengalami gejala somatik.

Kata kunci: gangguan mental emosional, mental emosional, SRQ-20
${ }^{1}$ Puskesmas Noemuti / RSUD

Kefamenanu, NTT, Indonesia

${ }^{2}$ Departemen Ilmu Kedokteran Jiwa dan Perilaku, Fakultas Kedokteran Universitas Katolik Indonesia Atma Jaya, Indonesia

\section{Korespondensi:}

Eduardo Renaldo

Puskesmas Noemuti / RSUD

Kefamenanu, NTT, Indonesia

Tlp: +6281295466317

Email: eduardo_renaldo@yahoo. com

J Biomedika Kesehat 2020;3(2):49-57 DOI: $10.18051 /$ JBiomedKes.2020. v3.49-57

pISSN: 2621-539X / eISSN: 2621-5470

Artikel akses terbuka (open access) ini didistribusikan di bawah lisensi Creative Commons Attribution 4.0 International (CC-BY 4.0) 


\section{ABSTRACT \\ Description of mental emotional disorders in Banfanu Village residents, North Central Timor, East Nusa Tenggara Province}

\section{BACKGROUND}

Mental health is one of the significant health problems in the world, including in Indonesia. Based on Riskesdas data, mental emotional disorders in the Indonesian population in 2013 were 6\%, while in 2018 it increased to 9.8\%. The province of East Nusa Tenggara (NTT) ranks the third highest with a prevalence of $15.7 \%$. In NTT, there has not been much research on mental emotional disorders, and there is no research that focuses on remote or underdeveloped areas in it. Therefore, this study intends to describe mental emotional disorder pattern among Banfanu village population through various accompanying sociodemographic factors.

\section{METHODS}

This study is an cross sectional study with accidental sampling on 80 respondents consist of Banfanu Village residents. The instrument used was the Self Reporting Questionnaire-20 (SRQ-20). Data analysis techniques in this study used frequency distribution. Data that has been classified, presented in tabular form.

\section{RESULTS}

From 80 respondents, $8.8 \%$ experiencing mental emotional disorders. Most of them were characterized by women $(6.3 \%)$, young age (15-34 years) by $5 \%$, low education (5\%), and unemployment (6.3\%). Somatic (physical) symptoms dominate both general population and those with mental emotional disorders. Some of the symptoms include headaches, sleep difficulty, fatigue, feeling anxious, tense or worried, poor appetite, and stomach discomfort.

\section{CONCLUSION}

The mental emotional disorders of the population in Banfanu Village, North Central Timor, East Nusa Tenggara Province were $8.8 \%$, and most experienced somatic symptoms.

Keywords: mental emotional disorders, mental emotional, SRQ-20

\section{PENDAHULUAN}

Kesehatan mental menurut World

Health Organization (WHO) merupakan suatu kondisi ketika seorang individu memahami betul kemampuan dan keterbatasan yang dimiliki olehnya, dapat mengatasi masalah atau stres yang dialami, bisa bekerja secara produktif, serta mampu memberikan kontribusi untuk masyarakat. Kesehatan jiwa adalah suatu kondisi sehat secara emosional, psikologis dan sosial yang terlihat dari hubungan interpersonal yang memuaskan, perilaku dan coping yang efektif, konsep diri yang positif serta stabilnya emosi seseorang. ${ }^{(1-3)}$

Kesehatan jiwa sendiri masih menjadi salah satu permasalahan kesehatan yang signifikan di dunia, termasuk di Indonesia. Di Indonesia, dengan berbagai faktor biologis, psikologis, dan sosial dengan keanekaragaman penduduk, maka jumlah kasus gangguan jiwa terus bertambah yang berdampak pada penambahan beban negara dan penurunan produktivitas manusia untuk jangka panjang. ${ }^{(4,5)}$ Menurut data WHO gangguan mental yang umum dijumpai adalah gangguan depresi dan cemas. Secara global, WHO memperkirakan bahwa sebanyak $4.4 \%$ populasi global mengalami gangguan depresi dan $3.6 \%$ diantaranya mengalami gangguan cemas. ${ }^{(6)}$

Pada tahun 2013, dilakukan riset kesehatan dasar (Riskesdas) pada penduduk Indonesia. Hasil riset didapatkan prevalensi penduduk Indonesia yang mengalami gangguan mental emosional yang ditunjukkan dengan gejala-gejala depresi dan kecemasan adalah sebesar $6 \%$. Berdasarkan hasil laporan Riskesdas tahun 2018, diketahui bahwa prevalensi gangguan mental emosional pada penduduk Indonesia mengalami peningkatan menjadi sebesar 9.8\%. Provinsi Nusa Tenggara Timur (NTT) menempati urutan ketiga tertinggi untuk prevalensi gangguan mental emosional setelah provinsi Sulawesi Tengah dan Gorontalo yakni $15.7 \%$. Angka ini jauh diatas angka nasional yang hanya sebesar 9.8\%. ${ }^{(7,8)}$ Hal ini dapat disebabkan oleh berbagai faktor sosiodemografik yang mempengaruhinya seperti jenis kelamin, usia, pendidikan rendah, bertempat tinggal di desa, maupun hambatan lain yang berada di daerah terpencil atau tertinggal. ${ }^{(9-11)}$

Peraturan Presiden Nomor 131 tahun 2015 tentang Penetapan Daerah Tertinggal tahun 2015-2019 menunjukkan sebanyak 18 dari 22 kabupaten di provinsi NTT ditetapkan sebagai daerah tertinggal tahun 2015-2019 dan kabupaten Timor Tengah Utara (TTU) dengan 249.711 jiwa penduduk sebagai salah satunya. ${ }^{(12,13)}$ Desa Banfanu yang berada di kecamatan Noemuti, kabupaten Timor Tengah Utara merupakan salah 
satu desa percontohan atau desa model di daerah TTU yang dianggap memiliki jumlah penduduk yang besar dan dapat menjadi modal pembangunan yang potensial. Jika kualitas sumber daya manusia (SDM) yang ada tidak memadai, maka penduduk dapat menjadi beban bagi pembangunan. Selain itu, saat ini sedang terjadi transisi kesehatan di berbagai daerah akibat bertambahnya usia harapan hidup, meningkatnya jumlah penduduk usia lanjut, dan meningkatnya insidens Penyakit Tidak Menular (PTM) yang menyebabkan dominasi jumlah kasus gangguan mental dan perilaku yang terus bertambah.

Di NTT, data-data mengenai gangguan mental emosional belum banyak dilakukan, serta belum terfokus pada daerah terpencil atau tertinggal yang ada di dalamnya. Berdasarkan pemaparan tersebut maka peneliti tertarik untuk menggambarkan pola gangguan mental emosional pada penduduk di Desa Banfanu, Kecamatan Noemuti, Kabupaten Timor Tengah Utara, Provinsi Nusa Tenggara Timur melalui berbagai faktor sosiodemografik yang menyertai.

Penelitian ini bertujuan untuk memperoleh informasi karakteristik (jenis kelamin, usia, pendidikan, dan pekerjaan) yang diharapkan dapat memberikan informasi bagi masyarakat luas serta dapat menjadi batu pijakan untuk penelitian dalam bidang gangguan mental emosional, terutama dalam bidang deteksi dini.

\section{METODE}

Penelitian ini merupakan penelitian cross-sectional yang melibatkan 80 responden di Desa Banfanu, Timor Tengah Utara, Provinsi Nusa Tenggara Timur. Subjek dari penelitian ini adalah penduduk di Desa Banfanu, kecamatan Noemuti, kabupaten Timor Tengah Utara, Provinsi Nusa Tenggara Timur. Subjek dipilih menggunakan accidental sampling. Peneliti mengambil seluruh sampel yang sesuai dengan kriteria inklusi dan eksklusi. Subjek dibatasi pada mereka yang berusia $\geq 15$ tahun. Namun, tidak ada pembatasan jenis kelamin, suku, maupun status sosioekonomi terhadap subjek penelitian. Besar sampel yang diperlukan pada penelitian ini dihitung menggunakan rumus besar sampel untuk studi potong lintang, dengan $\alpha=0.1$ dan prevalensi gangguan mental emosional sebesar $15.7 \%{ }^{(8)}$ Didapatkan sebanyak 50 subjek dengan perhitungan jumlah dropout sebesar $10 \%$, maka dibutuhkan total subjek minimal sebanyak 55 subjek.

Pengumpulan data dilakukan dengan menggunakan kuesioner Self Reporting Questionnaire-20 (SRQ-20) yang terdiri atas 20 butir pertanyaan yang hanya memerlukan jawaban "ya" atau "tidak". Kuesioner ini dapat dijawab langsung oleh responden, atau pada penduduk yang tidak mampu membaca dan dapat dibacakan oleh petugas.

Self-Reporting Questionnaire (SRQ) adalah kuesioner skrining gangguan psikiatri yang dikembangkan oleh World Health Organization (WHO) untuk keperluan penelitian seperti yang digunakan oleh Riskesdas untuk menilai kesehatan jiwa penduduk Indonesia. ${ }^{(7)}$ Kuesioner ini juga sudah memiliki validitas dan reliabilitas yang baik. Responden yang menjawab minimal 6 butir pertanyaan dengan jawaban "ya" dinyatakan mengalami gangguan mental emosional. Nilai batas pisah ini memiliki sesnitifitas 88\%, spesifisitas $81 \%$, positive predictive value (PPV) $60 \%$, dan negative predictive value (NPV) $92 \% .^{(14)}$ Data yang dikumpulkan menggunakan instrumen SRQ memiliki keterbatasan hanya mengungkap status emosional individu sesaat ( \pm 30 hari) dan tidak dirancang untuk mendiagnosis gangguan jiwa secara spesifik..$^{(7)}$

Teknik analisis data yang digunakan dalam penelitian ini menggunakan distribusi frekuensi. Pada tahap penyajian data, data yang sudah diklasifikasikan, disajikan atau ditampilkan dalam bentuk tabel.

Penelitian ini sudah mendapat persetujuan dari Komisi Kaji Etik Fakultas Kedokteran Universitas Katolik Indonesia Atma Jaya dengan nomor 12/10/KEP-FKUAJ/2019.

\section{HASIL}

Karakteristik umum responden yang dinilai diperlihatkan pada Tabel 1. Jumlah penduduk yang menjadi sampel penelitian sebanyak 80 responden terdiri dari 22 orang $(27.5 \%)$ berjenis kelamin laki-laki dan 58 orang $(72.5 \%)$ berjenis kelamin perempuan. Responden terbanyak (50\%) masuk kedalam kelompok umur muda (15-34 tahun) dengan sebagian besar responden terdiri dari mereka yang berusia 25-34 tahun (38.8\%). 
Status perkawinan responden dikelompokkan menjadi belum kawin, kawin, dan cerai (cerai mati atau cerai hidup). Pada pengelompokkan status kawin tidak dibedakan apabila responden sudah kawin secara adat maupun secara agama. Responden mayoritas memiliki status kawin (91.2\%).

Tabel 1. Karakteristik umum responden

\begin{tabular}{lcc}
\hline \multicolumn{1}{c}{ Karakteristik } & . Jumlah \\
\hline Jenis kelamin & & \% \\
Laki-laki & 22 & 27.5 \\
Perempuan & 58 & 72.5 \\
Kelompok umur & & \\
Umur muda (15-34) & 50 & 40 \\
Umur sedang (35-64) & 38 & 47.5 \\
Umur tua ( $\geq$ 65) & 2 & 2.5 \\
Status perkawinan & & \\
Belum kawin & 7 & 8.8 \\
Kawin & 73 & 91.2 \\
Cerai & 0 & 0 \\
Pendidikan & & \\
Pendidikan rendah & 43 & 53.8 \\
Pendidikan sedang & 16 & 20 \\
Pendidikan tinggi & 21 & 26.3 \\
Pekerjaan & & \\
Pegawai & 11 & 13.8 \\
Non-pegawai & 21 & 26.3 \\
Tidak bekerja & 48 & 60 \\
\hline
\end{tabular}

Pada latar belakang pendidikan, responden dikelompokkan ke dalam kategori pendidikan rendah apabila tidak pernah sekolah, tidak tamat SD, tamat SD, sampai tamat SMP. Responden yang tamat SMA dikategorikan ke dalam pendidikan sedang, dan apabila menempuh pendidikan di perguruan tinggi atau yang setara dikategorikan ke dalam pendidikan tinggi. Sebanyak 53.8\% responden memiliki latar belakang pendidikan yang rendah yang apabila ditinjau lebih lanjut pada tingkat pendidikan yang rendah ini, mayoritas responden tidak tamat SD $(15 \%)$, tamat SD (37.5\%), dan tamat SMP (1.3\%).

Pekerjaan dikelompokkan menjadi pegawai atau sekolah, yaitu pegawai negeri sipil, BUMN, TNI, Polri, pekerja swasta, dan pekerja tetap lainnya termasuk pensiunan yang mendapat uang pensiun setiap bulan. Responden yang belum bekerja karena sedang menempuh pendidikan juga dimasukkan ke dalam kelompok ini. Sedangkan non-pegawai adalah pekerjaan lain selain yang disebutkan diatas yaitu petani, nelayan, buruh, atau pekerjaan tidak tetap lainnya. Tidak bekerja adalah orang yang tidak memiliki pekerjaan pada sebagian besar aktivitas hariannya, ibu rumah tangga juga dikelompokkan menjadi tidak bekerja. Sebanyak 48 orang $(60 \%)$ responden masuk kedalam kelompok tidak bekerja yakni sebanyak $2.5 \%$ tidak memiliki pekerjaan dan 46 orang $(57.5 \%)$ yang terdiri dari 30 orang (37.5\%) ibu rumah tangga dan 16 orang (20\%) yang beraktivitas sebagai penenun. Pada kelompok pekerjaan non-pegawai kelompok ini di dominasi oleh mereka yang bekerja sebagai petani atau buruh tani $(26.3 \%)$ dan masing-masing hanya 3 orang responden $(3.8 \%)$ masuk ke dalam kelompok pegawai yakni PNS, pekerja swasta, dan wiraswasta.

Secara umum karakteristik responden memiliki komposisi yang di dominiasi oleh jenis kelamin perempuan pada latar belakang tingkat pendidikan, sudah kawin dan kelompok pekerjaan yang tidak bekerja. Sedangkan laki-laki mendominasi pada kelompok pekerjaan baik itu pegawai maupun non-pegawai.

Kuesioner SRQ-20 digunakan untuk mengetahui jumlah responden yang mengalami gangguan mental emosional. Berdasarkan Tabel 2 jumlah responden yang mengalami gangguan mental emosional sebesar $8.8 \%$.

Tabel 2. Prevalensi gangguan mental mosional

\begin{tabular}{ccc}
\hline $\begin{array}{c}\text { Gangguan Mental } \\
\text { Emosional }\end{array}$ & n & \%umlah \\
\hline Ya & 7 & 8.8 \\
Tidak & 73 & 91.2 \\
Total & 80 & 100 \\
\hline
\end{tabular}

Karakteristik penduduk yang paling banyak mengalami gangguan mental emosional adalah perempuan $(6.3 \%)$, usia muda (15-34 tahun) sebesar 5\%, pendidikan rendah (5\%), dan tidak bekerja (6.2\%) (Tabel 3).

Gejala terbanyak pada penduduk yang mengalami gangguan mental emosional ditampilkan pada Tabel 4. Gejala terbanyak yang berkaitan dengan gangguan mental emosional pada penduduk Desa Banfanu antara lain adalah sakit kepala, sulit tidur, mudah lelah, merasa cemas, tegang atau khawatir, dan tidak nafsu makan. Gejala tersebut merupakan gejala somatik (fisik). Dari Tabel 4 juga terlihat bahwa 4 dari 5 gejala yang banyak dialami oleh populasi umum 
juga dialami oleh kelompok yang mengalami gangguan mental emosional.

Tabel 3. Distribusi antara gangguan mental emosional dan karakteristik subjek

\begin{tabular}{|c|c|c|}
\hline \multirow{2}{*}{ Karakteristik } & \multicolumn{2}{|c|}{$\begin{array}{c}\text { Gangguan Mental } \\
\text { Emosional }\end{array}$} \\
\hline & $\begin{array}{l}\text { Ada* } \\
(\%)\end{array}$ & $\begin{array}{c}\text { Tidak ada** } \\
(\%)\end{array}$ \\
\hline \multicolumn{3}{|l|}{ Jenis kelamin } \\
\hline Laki-laki & 2.5 & 25 \\
\hline Perempuan & 6.3 & 66.3 \\
\hline \multicolumn{3}{|l|}{ Kelompok umur } \\
\hline Umur muda (15-34) & 5 & 45 \\
\hline Umur sedang (35-64) & 3.8 & 43.8 \\
\hline Umur tua $(\geq 65)$ & 0 & 2.5 \\
\hline \multicolumn{3}{|l|}{ Status perkawinan } \\
\hline Belum kawin & 1.3 & 7.5 \\
\hline Kawin & 7.5 & 83.8 \\
\hline Cerai & 0 & 0 \\
\hline \multicolumn{3}{|l|}{ Pendidikan } \\
\hline Pendidikan rendah & 5 & 48,8 \\
\hline Pendidikan sedang & 2.5 & 17.5 \\
\hline Pendidikan tinggi & 1.3 & 25 \\
\hline Pegawai & 1.3 & 12.5 \\
\hline Non-pegawai & 1.3 & 25 \\
\hline Tidak bekerja & 6.2 & 53.8 \\
\hline
\end{tabular}

Sakit kepala menempati posisi tertinggi, sulit tidur menempati urutan kedua diikuti dengan mudah lelah dan merasa tegang, cemas, atau kuatir yang menempati urutan ketiga dan keempat. Sama halnya seperti pada populasi umum, berbagai gejala somatik (fisik) juga mendominasi kelompok penduduk yang mengalami gangguan mental emosional. Lima gejala terbanyak antara populasi umum tidak berbeda dengan kelompok penduduk yang mengalami gangguan mental emosional. Perbedaan terletak pada gejala mengalami rasa tidak enak di perut yang menduduki peringkat ke lima pada kelompok gangguan mental emosional sedangkan pada populasi umum peringkat ke lima diduduki oleh gejala tidak nafsu makan (Tabel 5).

\section{PEMBAHASAN}

Penelitian dilakukan bertujuan untuk mengukur status kesehatan jiwa pada penduduk Desa Banfanu yang berada di kecamatan Noemuti, kabupaten Timor Tengah Utara yang menurut Peraturan Presiden Nomor 131 tahun 2015 masuk ke daerah yang tertinggal. ${ }^{(12)}$ Penelitian ini memperlihatkan gambaran pola gangguan mental emosional responden melalui berbagai faktor sosiodemografik yang menyertai seperti jenis kelamin, usia, status perkawinan, tingkat pendidikan, dan pekerjaan pada responden yang mengalami gangguan mental emosional.

Hasil penelitian ini menunjukkan prevalensi gangguan mental emosional pada penduduk desa Banfanu sebesar 8.8\%. Hasil tersebut lebih rendah dibandingkan dengan riset kesehatan dasar (Riskesdas) pada penduduk Indonesia oleh Badan Penelitian dan Pengembangan Kesehatan Republik Indonesia (Balitbangkes RI) yang dilakukan tahun 2018. Pada saat itu didapatkan prevalensi penduduk Indonesia yang mengalami gangguan mental emosional adalah sebesar 9.8\%. Sedangkan untuk provinsi NTT didapatkan angka prevalensi yang lebih tinggi yakni sebesar 15.7\%. ${ }^{(8)}$ Rendahnya angka prevalensi pada studi ini dapat terjadi karena responden penelitian bertempat tinggal di pedesaan yang memiliki faktor pencegah terjadinya gangguan mental emosional. Faktor pencegah ini antara lain dukungan sosial di lingkungan pedesaan dengan identitas suku, adat, budaya yang sama dan saling mendukung disertai relasi interpersonal yang lebih dekat dan bertahan lama sehingga menciptakan emosi yang stabil ${ }^{(15,16)}$. Selain itu, tersedianya tempat rekreasi alam yang terdiri dari ruangan terbuka hijau dan ruang terbuka biru yang seimbang kiranya memiliki hubungan terhadap kesehatan mental suatu populasi. ${ }^{(9,15)}$ Beberapa studi juga menunjukkan jika tinggal di daerah perkotaan berisiko lebih besar untuk memicu masalah kesehatan jiwa (seperti gangguan cemas, psikotik, mood, atau perilaku adiksi) dibandingkan tinggal di pedesaan. $(9,10,17,18)$ Hal ini diakibatkan tingginya jumlah polusi (air, udara, dan suara), tata letak kota yang buruk, dan tingginya ancaman fisik di perkotaan seperti kekerasan maupun kecelakaan..$^{(9)}$

Responden perempuan mengalami gangguan mental emosional lebih tinggi dibanding laki-laki. Gangguan mental emosional pada perempuan $6.3 \%$, sedangkan pada laki-laki $2.5 \%$. Hasil penelitian tersebut sesuai dengan studi baik di Indonesia maupun di berbagai negara lain. Di Indonesia, studi yang dilakukan Riskesdas tahun 2007 dan 2013 mendapatkan jika perempuan cenderung untuk mengalami gangguan mental emosional dengan odds ratio sebesar 1.4. Studi yang dilakukan di Canada juga menujukkan jika laki-laki memiliki risiko yang lebih rendah untuk mengalami gangguan afek atau mood $(\mathrm{OR}=0.62)$ 
Tabel 4. Distribusi penduduk secara umum dan kelompok yang mengalami gangguan mental emosional berdasarkan gejala yang dialami

\begin{tabular}{|c|c|c|c|c|}
\hline \multirow{2}{*}{ Butir pertanyaan } & \multirow{2}{*}{$\mathbf{n}^{1}$} & \multirow{2}{*}{$\%{ }^{1}$} & \multicolumn{2}{|c|}{$\begin{array}{l}\text { Terdapat gangguan } \\
\text { mental emosional }\end{array}$} \\
\hline & & & $n^{2}$ & $\%^{2}$ \\
\hline Sering sakit kepala & 49 & 53.8 & 6 & 7.5 \\
\hline Tidak nafsu makan & 17 & 21.3 & 4 & 5 \\
\hline Sulit tidur & 27 & 33.8 & 6 & 7.5 \\
\hline Mudah takut & 15 & 18.8 & 4 & 5 \\
\hline Merasa tegang, cemas atau kuatir & 18 & 22.5 & 5 & 6.3 \\
\hline Tangan gemetar & 5 & 6.3 & 2 & 2.5 \\
\hline Pencernaan terganggu/buruk & 2 & 2.5 & 1 & 1.3 \\
\hline Sulit untuk berpikir jernih & 2 & 2.5 & 1 & 1.3 \\
\hline Merasa tidak bahagia & 2 & 2.5 & 1 & 1.3 \\
\hline Menangis lebih sering & 4 & 5 & 2 & 2.5 \\
\hline Merasa sulit untuk menikmati kegiatan sehari-hari & 1 & 1.3 & 1 & 1.3 \\
\hline Sulit mengambil keputusan & 2 & 2.5 & 2 & 2.5 \\
\hline Pekerjaan sehari-hari terganggu & 0 & 0 & 0 & 0 \\
\hline Tidak mampu melakukan hal-hal bermanfaat dalam hidup & 0 & 0 & 0 & 0 \\
\hline Kehilangan minat pada berbagai hal & 0 & 0 & 0 & 0 \\
\hline Merasa tidak berharga & 0 & 0 & 0 & 0 \\
\hline Mempunyai pikiran untuk mengakhiri hidup & 0 & 0 & 0 & 0 \\
\hline Merasa lelah sepanjang waktu & 8 & 10 & 3 & 3.8 \\
\hline Mengalami rasa tidak enak di perut & 8 & 10 & 5 & 6.3 \\
\hline Mudah lelah & 18 & 22.5 & 6 & 7.5 \\
\hline
\end{tabular}

maupun gangguan cemas $(\mathrm{OR}=0.39) .{ }^{(10,11)}$

Pada perempuan yang bekerja dan telah berumah tangga, beban pekerjaan yang dimiliki dapat mempengaruhi emosi seseorang. Hasil penelitian sebelumnya memperlihatkan hubungan antara beban pekerjaan rumah tangga dengan gangguan mental emosional $(\mathrm{p}<0.0001)$. Pada penelitian tersebut prevalensi rasio 1.23 untuk confidence interval (CI) 95\%. Hal ini menunjukkan semakin tingginya beban pekerjaan rumah tangga maka akan semakin tinggi juga prevalensi gangguan mental emosional. ${ }^{(19)}$

Hasil penelitian ini memperlihatkan bahwa prevalensi gangguan mental emosional tertinggi pada responden kelompok usia 15-34 tahun, diikuti responden kelompok usia 35-64 tahun. Hasil penelitian ini sejalan dengan penelitian di Canada pada 2.433 individu yang memiliki rentang usia 15-65 tahun. Lebih jauh diperlihatkan bahwa laki-laki dan perempuan yang berusia lebih dari 55 tahun memiliki risiko yang paling rendah mengalami gangguan mental. Kelompok usia 25-34 tahun memiliki $(\mathrm{OR}=2.05)$, usia 35$44(\mathrm{OR}=2.39)$, dan usia 45-54 $(\mathrm{OR}=2.48)$. Hal ini menunjukkan faktor risiko gangguan mental sebanyak 2 kali lebih besar bila dibandingkan dengan mereka yang memiliki rentang usia 55 tahun keatas $(\mathrm{OR}=1.00) .{ }^{(11)}$ Berbeda dengan penelitian terdahulu yang menyatakan bahwa, usia tua selalu berpeluang lebih tinggi mengalami masalah emosional dibandingkan dengan usia lebih muda. Lebih terinci diungkapkan bahwa 33\% kelompok usia 35-64 tahun memiliki risiko mental emosional, sedangkan untuk kelompok usia $\geq 65$ tahun sebanyak $63 \%$. $^{(10,14)}$

Kelompokusiamudamerupakankelompok usia yang termasuk produktif untuk bekerja. Global Burden of Disease (GBD) menunjukkan jika secara global terdapat peningkatan kejadian gangguan mental yang signifikan pada populasi ini. Hal ini disebabkan karena kualitas pekerjaan yang buruk pada kelompok usia ini yang menjadi faktor risiko kuat dalam terjadinya gangguan mental. Kualitas pekerjaan yang buruk, seperti pekerjaan tanpa atau dengan kontrak kerja yang singkat dan pekerjaan dengan imbalan yang kurang memiliki dampak buruk yang bermakna pada kesehatan mental seseorang. ${ }^{(20)}$

Hasil penelitian ini memperlihatkan tingginya gangguan mental emosional pada tingkat pendidikan rendah (belum pernah sekolah atau hanya hingga tamat SD). Hasil penelitian lain memperlihatkan bahwa tingkat pendidikan berhubungan dengan distres psikologik atau 
Tabel 5. Lima gejala terbanyak pada penduduk umum dan kelompok yang mengalami gangguan mental emosional

\begin{tabular}{|c|c|c|c|}
\hline Gejala Populasi Umum & $\%$ & $\begin{array}{c}\text { Gejala Kelompok Gangguan Mental } \\
\text { Emosional }\end{array}$ & $\%$ \\
\hline Sering sakit kepala & 53.8 & Sering sakit kepala & 7.5 \\
\hline Sulit tidur & 33.8 & Sulit tidur & 7.5 \\
\hline Mudah lelah & 22.5 & Mudah lelah & 7.5 \\
\hline Merasa tegang, cemas, atau kuatir & 22.5 & Merasa tegang, cemas, atau kuatir & 6.3 \\
\hline Tidak nafsu makan & 21.3 & Mengalami rasa tidak enak di perut & 6.3 \\
\hline
\end{tabular}

gangguan mental emosional.Pendidikan yang lebih tinggi dari SMA memiliki korelasi negatif dengan kejadian distres psikologis. ${ }^{(11)}$ Penelitian lain mengungkapkan pendidikan rendah merupakan faktor yang memiliki hubungan tertinggi terhadap gangguan mental emosional. Penduduk berpendidikan rendah memiliki kecenderungan untuk mengalami gangguan mental emosional dua kali lipat lebih besar dibandingkan dengan penduduk yang berpendidikan tinggi. ${ }^{(10)}$

Pendidikan penting dalam membentuk emosi yang stabil. $^{(9)}$ Stabilnya emosi dan kemampuan memecahkan masalah memiliki efek jangka panjang dalam menghadapi berbagai masalah kehidupan di kemudian hari yang dapat meningkatkan risiko gangguan mental. ${ }^{(15)}$ Sekolah juga memiliki faktor penting sebagai institusi yang dapat memberikan informasi, edukasi dan peran preventif kepada berbagai kalangan populasi sejak usia dini. (20) Selain itu, pendapatan yang rendah dan kualitas pekerjaan yang buruk sering ditemukan pada orang dengan tingkat pendidikan yang rendah yang nantinya akan berdampak pada kesehatan mental yang lebih berisiko mengalami gangguan mental.(21)

Penduduk yang masuk ke dalam kelompok tidak bekerja mengalami gangguan mental emosional terbanyak pada penelitian ini. Hasil tersebut sesuai dengan beberapa penelitian baik yang dilakukan di luar negeri maupun di dalam negeri jika faktor tidak bekerja memiliki hubungan dengan gangguan mental emosional dan gangguan depresi. ${ }^{(10,22-24)}$ Selain itu, dukungan sosial yang buruk juga memiliki hubungan dengan status sosial dari seseorang yang tidak memiliki pekerjaan. Dibandingkan dengan mereka yang memiliki pekerjaan, orang yang tidak memiliki pekerjaan mengungkapkan kurangnya dukungan sosial yang berarti, kurangnya kontak sosial, relasi sosial yang buruk, dan cenderung terisolasi secara sosial. Hal ini menyebabkan buruknya kesehatan mental seseorang seperti peningkatan afek depresi, perasaan (mood) depresi, dan peningkatan perasaan-perasaan negatif lainnya. Selain itu, hal tersebut dapat mempengaruhi kemampuan dan fungsi yang pernah dimiliki di tempat kerja dan berakibat pada kecilnya kemungkinan bagi seorang individu untuk bisa diterima kembali bekerja. ${ }^{(25)} \mathrm{Hal}$ ini menyebabkan dampak timbal balik yang berkepanjangan pada kesehatan mental seseorang.

Gejala terbanyak yang dialami oleh responden adalah sering sakit kepala. Hal ini sesuai dengan studi yang menemukan bahwa gejala terbanyak yang dialami oleh penduduk Indonesia adalah sering sakit kepala ${ }^{(14)}$ sedangkan sebuah studi di Al Ain, Uni Emirat Arab (UEA) gejala terbanyak adalah merasa tegang, cemas, dan khawatir. ${ }^{(26)} \mathrm{Di}$ Indonesia gejala terbanyak adalah gejala yang berhubungan dengan keluhan somatik, sedangkan pada penduduk Al Ain gejala yang dialami adalah seimbang antara gejala somatik (sakit kepala, mudah lelah, dan sulit tidur) dengan psikologis lainnya seperti sulit mengambil keputusan, sulit berpikir jernih. ${ }^{(10,26)}$

Pada penelitian ini bila ditinjau pada populasi yang mengalami gangguan mental emosional, mereka juga memiliki gejala terbanyak yang berkaitan dengan gejala somatik. Hal ini berbeda dengan hasil studi oleh Riskesdas tahun 2007 dan 2013 yang mendapatkan gejalagejala yang berkaitan dengan depresi seperti mempunyai pikiran untuk mengakhiri hidup, tidak mampu melakukan hal yang bermanfaat dalam hidup, merasa tidak berharga, kehilangan minat pada berbagai hal, dan pekerjaan seharihari terganggu. ${ }^{(10)}$ Keanekaragaman budaya seperti adanya anggapan bahwa gangguan depresi akan hilang dengan sendirinya dapat memengaruhi tampilan klinis gangguan depresi. 
Hal ini menyebabkan ekspresi, interpretasi, dan respons sosial terkait gejala tersebut bervariasi dan mungkin menyebabkan seseorang tidak dapat mengekspresikan gejala depresi yang sebenarnya ingin disampaikan. ${ }^{(27)}$

Gejala-gejala somatik yang sering ditemukan di layanan kesehatan merupakan suatu alternatif dari "ungkapan stres" yang sering ditemukan pada budaya yang memberi stigma negatif pada gangguan psikiatri sehingga pasien mengungkapkan stresnya dengan gejala somatik. Keluhan somatik multipel ini dapat menjadi suatu bentuk ungkapan yang kemudian dipengaruhi oleh bahasa atau kebudayaan seseorang sehingga lebih dapat diterima secara sosial. Selain itu, penduduk dengan status ekonomi rendah di negara berkembang juga cenderung mengeluhkan gejala somatik dan menyangkal gejala psikologis nya karena kurang bersedia atau kurang mampu untuk mengungkapkan stres emosionalnya. ${ }^{(27)}$

Penelitian ini memiliki keterbatasan dimana penelitian ini menggunakan SRQ20 sebagai alat ukur sehingga hanya dapat mengungkap distres secara umum dan tidak dapat memberikan informasi spesifik jenis gangguan yang dialami. Pada penelitian selanjutnya, selain dapat dilakukan penilaian dengan menggunakan alat ukur yang lebih spesifik atau wawancara psikiatri, diperlukan pemberian terapi bagi orang yang mengalami keluhan fisik seperti sakit kepala, mudah lelah, sulit tidur, dan rasa tidak enak di perut untuk mengurangi gejala agar tidak berlanjut menjadi gangguan mental emosional yang menetap dan bahkan bertambah berat.

\section{KESIMPULAN}

Terdapat delapan koma delapan persen penduduk di Desa Banfanu, Timor Tengah Utara, Provinsi Nusa Tenggara Timur mengalami gangguan mental emosional, dengan gejala terbanyak yaitu sakit kepala, sulit tidur, mudah lelah, merasa cemas, tegang atau khawatir, dan tidak nafsu makan yang merupakan gejala somatik.

\section{KONFLIK KEPENTINGAN}

Pada penelitian ini tidak terdapat konflik kepentingan antara peneliti maupun dengan responden penelitian.

\section{REFERENSI}

1. World Health Organization. Preamble to the Constitution of the World Health Organization as adopted by the International Health Conference, New York, 19-22 June, 1946 [Internet]. Geneva, Switzerland: WHO; 1948 [cited 2019 Oct 2]. Available from: https://apps.who.int/iris/bitstream/ handle/10665/44192/9789241650472 eng. pdf? sequence $=1$

2. World Health Organization. Mental health [Internet]. Geneva, Switzerland: WHO; 2019 [cited 2019 Oct 2]. Available from: https:/www.who.int/ news-room/facts-in-pictures/detail/mental-health

3. World Health Organization. Mental health action plan 2013 - 2020 [Internet]. Geneva, Switzerland: World Health Organization; 2013. Available from: https://www.who.int/mental_health/publications/ action plan/en/

4. Ayuningtyas D, Misnaniarti, Rayhani M. Analisis situasi kesehatan mental pada masyarakat di Indonesia dan strategi penanggulangannya. JIKM 2018;9(1):1-10. doi: 10.26553/jikm.2018.9.1.1-10

5. Kementerian Kesehatan RI. Peran keluarga dukung kesehatan jiwa masyarakat. [Internet]. Jakarta: Kemenkes RI; 2016 [cited 2019 Oct 2]. Available from: http://sehatnegeriku.kemkes.go.id/baca/ rilis-media/20161006/4318188/peran-keluargadukung-kesehatan-jiwa-masyarakat/

6. World Health Organization. Depression and Other Common Mental Disorders: Global Health Estimates [Internet]. Geneva, Switzerland: World Health Organization; 2017. Available from: https://www.who.int/mental health/management/ depression/prevalence_global_health_estimates/ en/

7. Kementerian Kesehatan RI. Laporan Nasional Riskesdas 2013. Jakarta: Badan Penelitian dan Pengembangan Kesehatan; 2013. p.127-9.

8. Kementerian Kesehatan RI. Laporan Nasional Riskesdas 2018. Jakarta: Badan Penelitian dan Pengembangan Kesehatan; 2018. p. 229-30.

9. Gruebner O, Rapp MA, Adli M, et al. Cities and mental health. Dtsch Arztebl Int. 2017;114(8):1217. doi: 10.3238/arztebl.2017.0121

10. Idaiani S, Prihatini S, Suryaputri IY, et al. Pola gangguan mental emosional penduduk Indonesia: telaah riskesdas 2007 dan 2013 [Internet]. J Indon Med Assoc 2014 [cited 2019 Oct 2];64(4):170-6. Available from: http:// mki.idionline.org/index.php?uPage $=$ mki.mki $\mathrm{dl} \&$ smod $=$ mki\&sp $=$ public \&key=MzYxLTEw

11. Caron J, Fleury M, Perreault M, et al. Prevalence of psychological distress and mental disorders, and use of mental health services in the epidemiological catchment area of Montreal South-West. BMC Psychiatry 12, 183 (2012). doi: 10.1186/1471244X-12-183

12. Kementerian Hukum dan HAM RI. Peraturan Presiden Republik Indonesia Nomor 131 Tahun 2015 tentang Penetapan daerah tertinggal tahun 2015-2019 [Internet]. Jakarta: Kemenkumham RI; 2015 [cited 2019 Oct 2]. Available from: https:// peraturan.bpk.go.id/Home/Details/41885/perpresno-131-tahun-2015

13. Kementerian Kesehatan RI. Profil Kesehatan Provinsi Nusa Tenggara Timur Tahun 2017. NTT: Dinas Kesehatan Provinsi NTT; 2017

14. Idaiani S. Elderly people and women were more risk to mental disorders [Internet]. Health science 
Indonesia 2010;1(1):8-13. Available from: http:// ejournal.litbang.kemkes.go.id/index.php/HSJI/ article/view/28

15. Sax Institute. Evidence check: mental wellbeing risk \& protective factors [Internet]. Sydney: Sax Institute for VicHealth; 2019 [cited 2020 Feb 24]. Available from: https://s.id/17olk

16. Nepomuceno BB, Cardoso AAV, Ximenes VM, et al. Mental health, well being, and poverty: A study in urban and rural communities in Northeastern Brazil. J Prev Interv Community. 2016;44(1):6375. doi: $10.1080 / 10852352.2016 .1102590$

17. Jacobi F, Höfler M, Siegert J, et al. Twelve-month prevalence,comorbidity and correlates of mental disorders in Germany: the mental health module of the German health interview and examination survey for adults (DEGS1-MH). Int $\mathrm{J}$ Methods Psychiatr Res. 2014; 23(3): 304-19. doi: 10.1002/ mpr.1439

18. Long J, Huang G, Liang W, et al.The prevalence of schizophrenia in mainland China: evidence from epidemiological surveys. Acta Psychiatr Scand. 2014;130(4):244-56. doi: 10.1111/acps. 12296

19. Pinho PDS, Araújo TMD. Association between housework overload and common mental health disorders in women. Rev Bras Epidemiol. 2012;15(3):560-72. doi: 10.1590/s1415$790 \times 2012000300010$

20. World Health Organization \& the Calouste Gulbenkian Foundation. Social determinants of mental health [Internet]. Geneva: World Health Organization; 2014. Available from: https://www. who.int/mental health/publications/gulbenkian paper social_determinants of mental health/en/

21. Araya $\bar{R}$, Lewis G, Rojas $\bar{G}$, et al. Education and income: which is more important for mental health? J Epidemiol Community Health. 2003;57(7):5015. doi: 10.1136/jech.57.7.501

22. Talala K, Huurre T, Aro H, et al. Socio-demographic differences in self reported psychological distress among 25-64 year old Finns. Soc Indic Res. 2008;86:323-35. doi: 10.1007/s11205-007-9153-Z

23. Meyer OL, Castro-Schilo L, Aguilar-Gaxiola S. Determinants of mental health and selfrated health: a model of socioeconomic status, neighborhood safety, and physical activity. Am J Public Health. 2014;104(9): 1734-41. doi: 10.2105/AJPH.2014.302003

24. Rapp MA, Kluge U, Penka S, et al. When local poverty is moreimportant than your income: Mental health in minorities in innercities. World Psychiatry 2015; 14: 249-50.doi: 10.1002/ wps.20221

25. Hergenrather $\mathrm{KC}$, Zeglin RJ, McGuire-Kuletz $\mathrm{M}$, et al. Employment as a social determinant of health: A review of longitudinal studies exploring the relationship between employment status and mental health. Rehabilitation Research, Policy, and Education. 2015; 29(1): 261-90. doi: 10.1891/2168-6653.29.3.261

26. Abou-Saleh MT, Ghubash R, Daradkeh TK. Al Ain community psychiatric survey. I. Prevalence and sociodemographic correlates. Soc Psychiatr Epidemiol. 2001;36:20-8. doi: 10.1007/ s001270050286

27. Mayangsari C, Redayani P, Diatri H. Ungkapan stres untuk gejala cemas dan depresi pada pasien di puskesmas gambir (studi kualitatif) [Internet]. J Indon Med Assoc. 2016[cited 2020 Mar 4]; 66(10):481-9. Available from: http:// staff.ui.ac.id/system/files/users/petrin.redayani /publication/ungkapan_stres_untuk_gejala_ cemas.pdf 